\title{
Hoe computerisering de arbeidsmarkt verandert: de feiten op een rij vanuit een nieuw raamwerk
}

\author{
Citation for published version (APA):
}

Borghans, L., \& ter Weel, B. J. (2000). Hoe computerisering de arbeidsmarkt verandert: de feiten op een rij vanuit een nieuw raamwerk. Researchcentrum voor Onderwijs en Arbeidsmarkt, Faculteit der Economische Wetenschappen. ROA Working Papers No. 7 https://doi.org/10.26481/umarow.2000007

Document status and date:

Published: 01/01/2000

DOI:

10.26481/umarow.2000007

Document Version:

Publisher's PDF, also known as Version of record

\section{Please check the document version of this publication:}

- A submitted manuscript is the version of the article upon submission and before peer-review. There can be important differences between the submitted version and the official published version of record. People interested in the research are advised to contact the author for the final version of the publication, or visit the DOI to the publisher's website.

- The final author version and the galley proof are versions of the publication after peer review.

- The final published version features the final layout of the paper including the volume, issue and page numbers.

Link to publication

\footnotetext{
General rights rights.

- You may freely distribute the URL identifying the publication in the public portal. please follow below link for the End User Agreement:

www.umlib.nl/taverne-license

Take down policy

If you believe that this document breaches copyright please contact us at:

repository@maastrichtuniversity.nl

providing details and we will investigate your claim.
}

Copyright and moral rights for the publications made accessible in the public portal are retained by the authors and/or other copyright owners and it is a condition of accessing publications that users recognise and abide by the legal requirements associated with these

- Users may download and print one copy of any publication from the public portal for the purpose of private study or research.

- You may not further distribute the material or use it for any profit-making activity or commercial gain

If the publication is distributed under the terms of Article $25 \mathrm{fa}$ of the Dutch Copyright Act, indicated by the "Taverne" license above, 


\title{
Hoe computerisering de arbeidsmarkt verandert: de feiten op een rij vanuit een nieuw raamwerk
}

\author{
ROA-W-2000/7
}

Lex Borghans en Bas ter Weel*

\footnotetext{
* Lex Borghans: Researchcentrum voor Onderwijs en Arbeidsmarkt (ROA), Universiteit Maastricht. Bas ter Weel: Maastricht Economic Research institute on Innovation and Technology (MERIT), Universiteit Maastricht. We willen Harrie Borghans, Andries de Grip en Hugo Hollanders graag bedanken voor hun commentaar op een eerdere versie.
}

\section{Researchcentrum voor Onderwijs en Arbeidsmarkt}

Faculteit der Economische Wetenschappen en Bedrijfskunde Universiteit Maastricht

Maastricht, november 2000 
ISBN 90-5321-297-3

Sec00163/LB 
Inhoud

Bladzijde

Samenvatting

1 Inleiding 1

2 Bevindingen 5

3 De impact van ICT op de werkplek 16

3.1. Wie gebruikt ICT? 17

3.2. Productiviteit, vraag en loon 20

3.3. Welke vaardigheden zijn belangrijk? $\quad 20$

3.4. Het gevraagde opleidingsniveau 21

3.5. Wordt het werk complexer of meer gestandaardiseerd? 22

4 Conclusies 22

5 Literatuur 24 



\section{Samenvatting}

De digitalisering van de wereld, als gevolg van de introductie van computers, chips en moderne informatie- en communicatietechnologie (ICT), is ongetwijfeld de belangrijkste technologische ontwikkeling van de afgelopen decennia. Op grond van het feit dat steeds meer werkenden met computers te maken krijgen, wordt vaak de conclusie getrokken dat computervaardigheden steeds meer de sleutel tot maatschappelijk succes zullen gaan worden. Het doel van deze paper is een bijdrage te leveren aan de discussie over de invloed van ICT op werk. De belangrijkste conclusies zijn dat de vrees voor een tweedeling in de maatschappij ongegrond lijkt. Hoewel computers aanvankelijk vooral hun intrede doen bij hoger opgeleiden zal na verloop van tijd vrijwel elke werknemer met computers in aanraking komen. Ontbrekende computervaardigheden spelen waarschijnlijk geen belemmerende rol tijdens deze computerisering. Dit betekent echter niet dat er geen beleid gevoerd hoeft te worden om de economische potentie van ICT zo goed mogelijk te benutten. Allereerst kan een goede ontwikkeling van de infrastructuur van belang zijn voor een snelle diffusie van de mogelijkheden die ICT biedt. Het gaat hierbij niet alleen om de fysieke netwerken, maar ook om de beschikbaarheid van software en informatie. Daarnaast wordt verwacht dat over de gehele linie de opleidingseisen voor werknemers zullen toenemen. Er zullen ook zeker veranderingen optreden in de kennis en vaardigheden waarover mensen dienen te beschikken. Het zal hierbij echter niet in de eerste plaats gaan om computervaardigheden, maar om een veel bredere verschuiving van het belang van diverse vaardigheden in onze samenleving. Om adequaat op deze veranderingen te kunnen inspelen zijn betrouwbare gegevens dus van groot belang. Wat wordt gemeten en de manier waarop gemeten wordt, zal aanzienlijk moeten veranderen. 


\section{Inleiding}

Nieuwe machines worden vaak als een bedreiging gezien. Hoewel er meestal grote waardering bestaat voor het vernuft van de uitvinder die de eerste automobiel, radio of schakende machine maakt, en veel mensen een dergelijk wonder met eigen ogen willen aanschouwen, ontstaat dikwijls de angst voor de veranderingen die de introductie van nieuwe technieken en technologie met zich mee zal brengen. Uiteraard is deze angst ten dele terecht. De film Modern Times van Charlie Chaplin uit 1936 laat een slachtoffer van een lopende band zien, die in een psychiatrische inrichting terechtkomt en zelfs daar gelukkiger is dan aan de lopende band. Daarnaast is er de koetsier, die zo handig was in de omgang met zijn paarden, maar na de entree van de auto niet veel meer aan deze vaardigheden had, net zoals de verdere ontwikkeling van schaakcomputers de prestaties van de schaakprofessionals in een ander daglicht zal plaatsen. De vrees voor verlies van werk is daarom vaak een bron van verzet tegen de introductie van nieuwe technologie. Als vele jaren later iedereen gewend is aan de nieuwe technologie en de maatschappij zich heeft aangepast aan de mogelijkheden ervan, wordt echter herhaaldelijk lacherig teruggekeken op de angst voor het nieuwe en onbekende. Opmerkelijk genoeg blijken de implicaties van de nieuwe techniek of technologie veel groter te zijn geweest dan men aanvankelijk kon bevroeden, waardoor ook veel nieuwe werkgelegenheid is ontstaan.

Zowel bij de introductie van de computer in de jaren zestig en de opkomende automatisering in de jaren zeventig, als bij de wijde verspreiding van PC's, de opkomst van het Internet in de jaren tachtig en negentig en de huidige innovaties op het gebied van de (mobiele) telecommunicatie, heerst de vrees dat mensen hun werk zullen verliezen of dat delen van de bevolking de boot zullen missen en er een (digitale) tweedeling in de samenleving zal ontstaan.

Aanvankelijk werd de computer vooral gezien als een apparaat dat werk van mensen overnam en efficiënter uitvoerde. De eerste computergestuurde robots lasten, spoten en construeerden auto's die eerst door mensenhanden in elkaar werden gezet; computers namen administratieve werkzaamheden van boekhouders over; en computers namen in de procesindustrie op basis van meetgegevens uit de fabriek zelfstandig beslissingen over de voortgang van het productieproces. Het beeld bestond dat de computer steeds meer werk zou overnemen van de mens. In de toekomst zou waarschijnlijk ook de vertaler plaats moeten maken voor een vertaalcomputer. Onder veel economen, maar vooral onder de bevolking, bestond dan ook de vrees dat de computer en ICT veel werk van de mensen zou overnemen en grote groepen uit de bevolking werkloos zouden worden ${ }^{1}$. Omdat het makkelijker is eenvoudig werk te automatiseren zouden met name de lager opgeleiden de dupe worden van de opkomst van de computer. Spenner (1985) bracht naar voren dat de vraag naar arbeid steeds meer een 'u-vormig' verloop zou krijgen. Aan de ene kant zou veel hooggeschoolde arbeid nauwelijks beïnvloed worden door de computerisering; de opkomst van de computer vraagt zelfs om steeds meer hooggeschoolde deskundigen, die computers ontwik-

1. Zie onder meer Soete (1987) en Freeman \& Soete $(1994 ; 1997)$ voor een overzicht van deze gedachtegang. 
kelen, draaiende houden en programmatuur schrijven, terwijl aan de andere kant het werk van lager opgeleiden - als ze het al behouden - steeds simplistischer zou worden. Zij hoeven alleen nog maar op de knop te drukken om de machine aan te zetten en toe te kijken of alles naar wens verloopt. Het ambachtelijke werk of vakmanschap in het midden van het spectrum zou verdwijnen. De figuren 1 en 2 laten zien dat bij het prille begin van de computerrevolutie deze 'u-vorm' inderdaad gestalte leek te krijgen.

Figuur 1

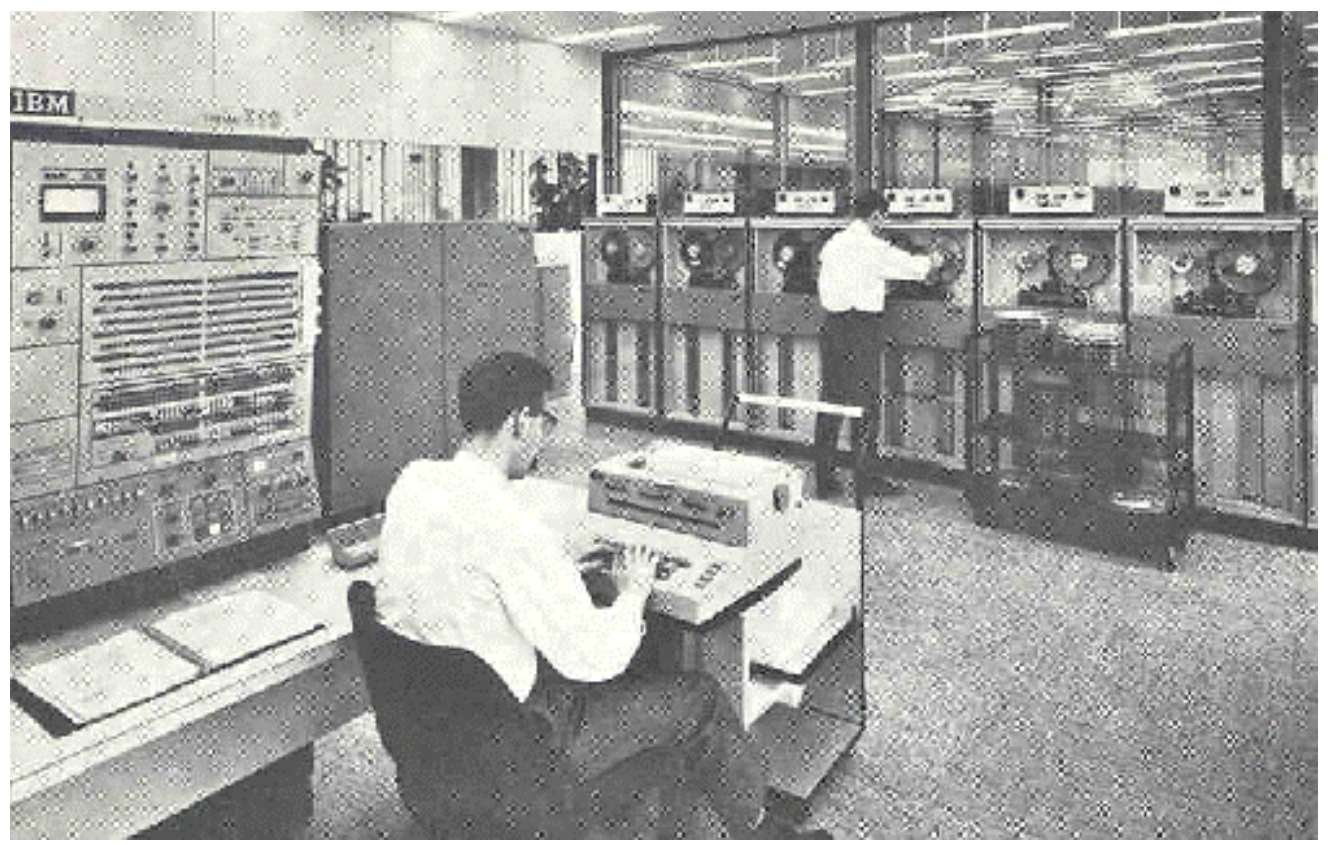

Computeroperators bedienen een IBM sytem 360 , model 50 . Het is duidelijk dat het bedienen van een computer in de jaren zestig veel computervaardigheid vereiste.

Bron: Lohberg \& Lutz (1968)

De dramatische toename van de werkloosheid in Europa sinds het einde van de jaren zeventig leek voor veel mensen te bevestigen dat door automatisering veel werk verloren zou gaan. Deze vrees voor verlies van werkgelegenheid als gevolg van de opkomst van de computer bepaalde lang het werkgelegenheidsbeleid. Het Europese Witboek Groei, Concurrentievermogen, Werkgelegenheid: Naar de 21ste Eeuw: Wegen en Uitdagingen uit 1994 heeft het in haar analyse van werkloosheid dan ook nog steeds over technologische werkloosheid. Het doembeeld van massale technologische werkloosheid is echter nooit realiteit geworden. Zoals de OESO (1994) het stelt: 'History does not support the case for technological unemployment' Hier zijn twee redenen voor aan te wijzen.

Ten eerste heeft de computer niet alleen werk overgenomen dat voorheen ook al werd gedaan, maar heeft deze nieuwe technologie in al zijn verschijningsvormen ook een enorm scala aan mogelijkheden geboden voor nieuwe producten, nieuwe werkwijzen en enorme besparingen op de kosten van bepaalde productieprocessen. 


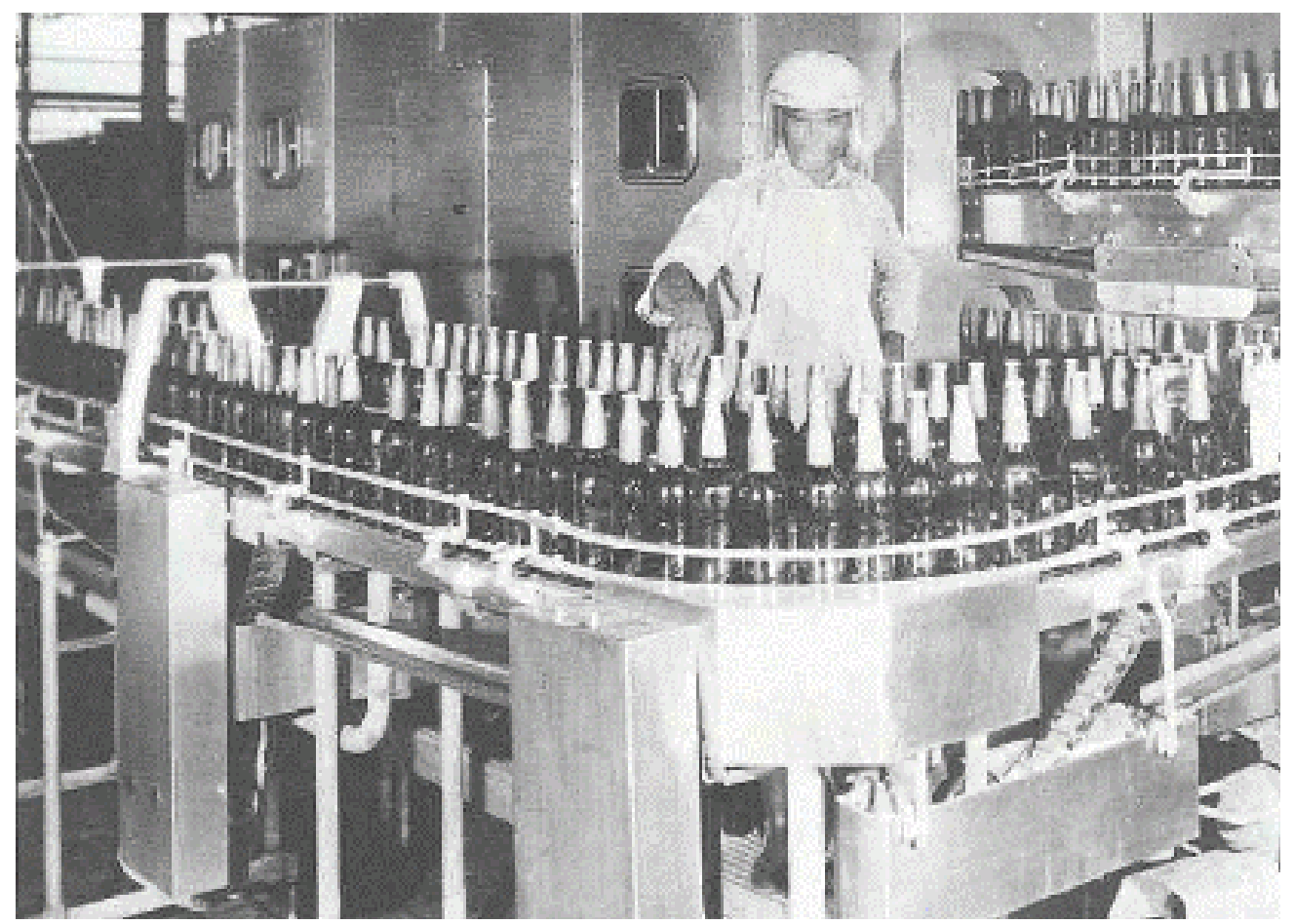

Een man houdt het productieproces in de gaten. Af en toe grijpt hij even in.

Bron: Reader (1980)

Door de nieuwe mogelijkheden zijn talloze nieuwe banen ontstaan die niet alleen hoger opgeleide arbeidskrachten vragen. Voorbeelden van nieuwe producten zijn de talloze elektronische apparaten, zoals digitale horloges, computerspelletjes, maar ook de mobiele telefoons die niet alleen in de ontwikkeling, maar ook in de assemblage en de verkoop veel werk hebben gegenereerd. Call centers en helpdesks zijn de belangrijkste voorbeelden van nieuwe werkwijzen die slechts door de computertechnologie mogelijk zijn geworden en met name veel werk voor personeel op middelbaar niveau hebben opgeleverd. Doordat eenmaal ontwikkelde software relatief eenvoudig kan worden aangepast aan nieuwe toepassingen, zijn de productiekosten van veel apparaten aanzienlijk gedaald. Waar vroeger in een televisie met voorkeurtoetsen voor elke toets een aparte, dure en kwetsbare elektronische schakeling moest worden opgenomen, is nu de aanpassing van een op afstand bedienbare televisie van 12 naar 100 voorkeurzenders slechts een marginale verandering van een parameter in de desbetreffende software.

De tweede reden waarom het doembeeld van massawerkloosheid nooit realiteit is geworden, is dat inmiddels is gebleken dat de computer niet zozeer werknemers vervangt, maar dat werknemers steeds meer met een computer gaan samenwerken. Technologie is zich steeds meer aan gaan passen aan de gebruikers, in plaats van aanpassing van werk en organisatie aan de technologie, zoals veelal wordt verondersteld. De nieuwe technologie wordt hierbij veelal gezien als een extern gegeven, waarover uiteindelijk geen controle mogelijk is 
en waaraan de mens zich dient aan te passen. Door niet mee te gaan met de moderne techniek zou de internationale concurrentiepositie van het land of onderneming in gevaar kunnen komen met alle negatieve gevolgen van dien. Dat de computer een heel andere rol heeft gekregen wordt duidelijk weerspiegelt in de term personal computer, omdat de PC de symbiose tussen mens en machine uitstekend symboliseert. Terwijl aan het begin van de jaren tachtig nog nauwelijks computers op het bureau te vinden waren, zijn de PC's inmiddels zowel op het werk als ook in toenemende mate thuis niet meer weg te denken ${ }^{2}$. Inmiddels heeft in Nederland $72 \%$ van de huishoudens thuis een computer ter beschikking en ligt het gebruik van een computer op het werk nog hoger ${ }^{3}$.

Door deze snelle toename in het gebruik van PC's heeft de vrees dat de computer het werk zal overnemen, plaatsgemaakt voor de vrees dat mensen niet met de computer om kunnen gaan. Met termen als 'digibeet' wordt op het gevaar gewezen dat we over enige tijd worden geconfronteerd met het feit dat slechts een deel van de bevolking overweg kan met een computer $^{4}$. Opnieuw wordt dus gevreesd voor een tweedeling in de maatschappij. Om er voor te zorgen dat iedereen om leert te gaan met de computer worden omvangrijke investeringen gedaan in computers op scholen, krijgen alle leerlingen een e-mailadres en overweegt men fiscale voordelen te introduceren bij de aanschaf van PC's. Deze maatregelen moeten ervoor zorgen dat zo min mogelijk mensen de boot missen.

Hoewel de kijk op de invloed van computers op werkgelegenheid sterk is veranderd, blijft de diagnose dat met name hoger opgeleiden van deze nieuwe technologie zullen profiteren, terwijl lager opgeleiden het risico lopen niet mee te kunnen met deze ontwikkelingen. Sinds David Ricardo's werk in de negentiende eeuw is veel geschreven over deze relatie tussen technologische ontwikkeling en werkgelegenheid (Ricardo, 1821). Centrale vraag is steeds of deze technologische ontwikkelingen met name de vraag naar lager opgeleiden doen verminderen. Tegenwoordig heet dit het debat over 'skill-biased technical change ${ }^{15}$. Onder economen lijkt een steeds grotere consensus te ontstaan over het feit dat technologische veranderingen de afgelopen zestig jaar niet louter productiviteitsverhogend en dus arbeids-

2. Zie Ter Weel (2000) voor een analyse van de aanpassing van technologie aan de vaardigheden van de mens.

3. In het onderwijs is de PC ook ingetreden. Het aantal leerlingen per PC in Nederland was in 1999 21,8. In de Verenigde Staten lag het aantal leerlingen per PC veel lager: 8,0. In Canada is de ratio 9,8, in Finland 15,1, in Noorwegen 15,4, in het Verenigd Koninkrijk op 18,0, in Nieuw Zeeland op 18,4, in Frankrijk op 25,1, in Japan op 36,1 en in Italië op 92,6 leerlingen per computer (zie Anderson \& Ronnkvist, 1999).

4. De Angelsaksische polarisatie van arm en rijk zou als gevolg van de voortschrijdende technologie een soort 'haves' en 'have-nots' creëren: een samenleving van individuen die goed overweg kunnen met ICT en alles wat daaromheen hangt en een goede boterham verdienen tegenover een groep ICT-analfabeten, die arm zijn en geen baan kunnen vinden tegen een redelijke vergoeding en derhalve werkloos achterblijven.

5. Een Nederlandse term voor dit fenomeen is niet voorhanden. Vandaar dat we de Engelse term in dit stuk blijven gebruiken. 
verminderend zijn, maar dat er inderdaad een toenemende vraag naar hoger opgeleiden is ${ }^{6}$. Griliches (1969) en Acemoglu (1998) constateren dat hooggeschoolde arbeid complementair is aan kapitaal, terwijl laaggeschoolde arbeid en kapitaal elkaar substitueren ${ }^{7}$. Door de opkomst van moderne ICT is deze 'upgrading' van de vraag naar arbeid waarschijnlijk in een stroomversnelling geraakt, ondanks het grotere aanbod van hooggeschoolden sinds de jaren zestig in de meeste OESO-landen.

Er is echter zeker nog geen consensus over de wijze waarop de computer en andere nieuwe technieken de arbeidsmarkt veranderen. De in veel studies aangetroffen complementariteit tussen hooggeschoolde arbeid en kapitaal is een puur statistische constatering. Als de hoeveelheid kapitaal toeneemt stijgt ook de vraag naar hoger opgeleiden. Er is echter nog maar weinig duidelijk over hoe dit proces in zijn werk gaat. Om de consequenties van de opkomst van ICT goed te overzien is het van belang om meer inzicht te verkrijgen in de manier waarop deze technologie het werk verandert. In deze paper zullen we laten zien dat net zoals het beeld dat computers het werk van laaggeschoolden overnemen onjuist bleek te zijn, ook het beeld dat alleen mensen die om kunnen gaan met computers mee kunnen op de arbeidsmarkt van de 21ste eeuw aan geloofwaardigheid lijkt te verliezen. Hoewel de complementariteit tussen kapitaal en hooggeschoolde arbeid niet ter discussie staat, is voor beleid ten aanzien van onderwijs, scholing en werkgelegenheid, maar ook voor technologiebeleid en beleid gericht op de internationale concurrentiepositie, een adequaat beeld van de betekenis die de computer heeft voor het werk echter van groot belang.

Allereerst zullen we daartoe in paragraaf 2 de belangrijkste bevindingen over computers op het werk op een rij zetten. In paragraaf 3 bespreken we op basis van een analyse van de interactie tussen mens en machine, op welke wijze deze bevindingen verklaard kunnen worden en welke implicaties dit heeft voor de ontwikkelingen op de arbeidsmarkt. In paragraaf 4 lichten we toe wat de betekenis van deze analyse is voor het beleid.

Het is tekenend dat in Nederland nog nauwelijks pogingen zijn ondernomen deze arbeidsmarktontwikkelingen serieus in kaart te brengen. In deze paper zullen we de ontwikkelingen die het gevolg zijn van de introductie van de computer dan ook moeten toelichten aan de hand van gegevens over het Verenigd Koninkrijk.

\section{Bevindingen}

In een baanbrekend artikel vraagt Alan Krueger (1993) zich af hoe computers de loonstructuur hebben gewijzigd. In zijn artikel komen twee belangrijke bevindingen naar voren. Ten eerste laat hij zien dat computers in de Verenigde Staten in de jaren 1984-1989 met name worden gebruikt door hoger opgeleiden. Met de snelle diffusie van computers neemt welis-

6. Zie onder meer de studies van Katz \& Murphy (1992), Goldin \& Katz (1998) en Murphy \& Welch (2000).

7. Voor Nederland is deze relatie aangetoond door Broer \& Jansen (1989) en Hebbink (1991). 
waar ook het gebruik onder lager opgeleiden toe, maar op ieder moment in de tijd is de penetratiegraad hoger naarmate het opleidingsniveau stijgt. Zonder er expliciet op in te gaan laat Krueger hiermee zien dat de veronderstelling dat automatisering vooral werk van lager opgeleiden zou versimpelen en zelfs over zou nemen niet juist is. Er blijkt eerder sprake te zijn van een directe samenwerking tussen computers en hoger opgeleiden. Ook voor andere landen en andere periodes wordt dit verband tussen opleidingsniveau en computergebruik geconstateerd. Tabel 1 geeft een beeld van computergebruik in 1992 en 1997 in het Verenigd Koninkrijk voor de zes opleidingsniveaus die daar worden onderscheiden. Uit deze cijfers blijkt ook dat het computergebruik op de werkplek steeds hoger wordt. Van de universitair opgeleiden gebruikt in 1997 zelfs 96\% een computer. Voor HBO'ers ligt dit percentage op $89 \%$. Bij de hoger opgeleiden begint een verzadiging op te treden, maar het gebruik van de computer blijft toenemen, dwars door de kwalificatiedistributie heen. De totale stijging in computergebruik in de periode $1992-1997$ is maar liefst $46 \%$. De grootste stijging in computergebruik wordt behaald door werknemers die geen diploma hebben, terwijl op middelbaar niveau de stijging ook hoger is dan aan de top.

Tabel 1

Gebruik van computers op het werk bij werkenden in het Verenigd Koninkrijk in 1992 en 1997 per opleidingsniveau

Opleidingsniveau

Computergebruik 1992

$(\%)$

Computergebruik 1997

(\%)

Procentuele toename 1992-1997

\begin{tabular}{|c|c|c|c|}
\hline $\begin{array}{l}\text { Degree } \\
\text { Universiteit }\end{array}$ & 67 & 96 & 43 \\
\hline $\begin{array}{l}\text { Professional Qualifi- } \\
\text { cation } \\
H B O\end{array}$ & 66 & 89 & 34 \\
\hline $\begin{array}{l}\text { NVQ } 3 \\
\text { MBO niveau } 2 \text { en } 3\end{array}$ & 51 & 75 & 47 \\
\hline $\begin{array}{l}\text { NVQ } 2 \\
K M B O\end{array}$ & 47 & 72 & 53 \\
\hline $\begin{array}{l}\text { NVQ } 1 \\
\text { VBO of MBO assis- } \\
\text { tentenopleiding }\end{array}$ & 38 & 55 & 44 \\
\hline $\begin{array}{l}\text { No Qualification } \\
\text { Geen Diploma }\end{array}$ & 25 & 40 & 61 \\
\hline $\begin{array}{l}\text { Totale Beroepsbevol- } \\
\text { king }\end{array}$ & 47 & 69 & 46 \\
\hline
\end{tabular}

De tweede belangrijke bevinding van Krueger is dat een sterk verband blijkt te bestaan tussen salaris en computergebruik. Omdat met name hoger opgeleiden computers blijken te gebruiken, lijkt dit een voor de hand liggende relatie. Krueger laat echter zien dat zelfs als wordt gecorrigeerd voor opleidingsniveau, beroep en een aantal andere gebruikelijke verklaringen voor het salaris, computergebruikers nog steeds aanzienlijk meer blijken te verdie- 
nen. Bij Krueger is deze computerpremie 15,0\% in 1984 en neemt toe tot $17,6 \%$ in 1989 . Uit later werk van Autor, Katz \& Krueger (1998) blijkt dat deze computerpremie in 1993 is gestegen naar $22,5 \%$. Deze analyse is inmiddels talloze malen voor verschillende landen, verschillende jaren en met verschillende databronnen uitgevoerd ${ }^{8}$. Steeds opnieuw wordt een aanzienlijke computerpremie gevonden. Autor, Katz \& Krueger observeren daarnaast dat computers leiden tot een verschuiving in de vraag naar arbeid in het voordeel van hoger opgeleiden ${ }^{9}$.

Ook wij vinden voor het Verenigd Koninkrijk een soortgelijke computerpremie. Tabel 2 laat zien dat deze premie in 1997 21,4\% bedraagt. Op basis van de data die voor het Verenigd Koninkrijk beschikbaar zijn, kan ook een verband worden gelegd met de mate van computergebruik. Uit de tabel blijkt dat naarmate het computergebruik essentiëler wordt, de desbetreffende computerpremie stijgt.

Krueger trekt uit zijn bevindingen de conclusie dat computervaardigheden een essentiële rol op de arbeidsmarkt zijn gaan spelen. Computers blijken niet het werk van laaggeschoolden over te nemen, maar vragen om vaardigheden waarover met name hooggeschoolden lijken te beschikken. Om die reden worden computers in eerste instantie met name bij hooggeschoolden ingezet en blijkt zelfs dat (gegeven het opleidingsniveau) degenen die een computer gebruiken aanmerkelijk meer verdienen dan degenen die geen computer gebruiken. Kennelijk beschikt niet iedereen in gelijke mate over deze computervaardigheden. Vandaar dat de schaarste aan computervaardigheden het loon van mensen met computervaardigheden heeft opgedreven. Met het toenemende gebruik van computers zijn werkgevers steeds meer mensen in gaan zetten die over minder computervaardigheden beschikken. De premie voor adequate computervaardigheden is daardoor alleen maar verder toegenomen, volgens het allocatie-argument van Krueger cum suis.

De gedachte dat computers werk van laaggeschoolden overnemen, heeft dus plaatsgemakkt voor de gedachte dat alleen hooggeschoolden deze computer kunnen bedienen. Caselli (1999, blz. 78) verwoordt het zo: 'A technological revolution is the introduction of new

8. Studies voor andere landen zijn Miller \& Mulvey (1997) voor Australië, Reilly (1995) voor Canada, Entorf \& Kramarz (1997) en Entorf, Gollac \& Kramarz (1999) voor Frankrijk, DiNardo \& Pischke (1997) en Borghans \& Ter Weel (2000b) voor Duitsland, Oosterbeek (1997) en Borghans \& Van Loo (1999) voor Nederland, Machin (1996), Green (1999), Green, Felstead \& Gallie (1999) en Haskel \& Heden (1999) voor het Verenigd Koninkrijk, en Berman, Bound \& Griliches (1994), Levy \& Murnane (1996), Doms, Dunne \& Troske (1997), Autor, Katz \& Krueger (1998), Bresnahan, Brynjolfsson \& Hitt (1998), Katz (1999), Dunne, Foster, Haltiwanger \& Troske (2000) en Weinberg (2000) voor de Verenigde Staten. Studies voor meerdere landen zijn onder andere Caroli \& Van Reenen (1998) voor Frankrijk en het Verenigd Koninkrijk, Card, Kramarz \& Lemieux (1999) for Canada, Frankrijk en de Verenigde Staten, en Berman, Bound \& Machin (1998) Machin \& Van Reenen (1998) en Desjonqueres, Machin \& Van Reenen (1999) voor verschillende OESO-landen.

9. Zie Chennells \& Van Reenen (1999) en Sanders \& Ter Weel (2000) voor een overzicht van deze studies. 
types of machines. Machines of the new type are more productive than machines of the preexisting types, but they can only be operated by workers who have developed a set of machine-specific skills. The acquisition of such skills is costly, and the labor force is of course heterogeneous in the cost of acquisition. The revolution is skill-biased if the new skills are more costly to acquire than the skills required to operate the old machine. On the other hand, the revolution is de-skilling if the new skills can be acquired at a lower cost than the skills associated with pre-existing technologies.'

Tabel 2

Computerpremie in het Verenigd Koninkrijk in 1997 gerelateerd aan het belang van computergebruik

$\begin{array}{lr}\text { Essentieel } & 34,0 \\ \text { Behoorlijk belangrijk } & 23,6 \\ \text { Redelijk belangrijk } & 14,7 \\ \text { Niet erg belangrijk } & 12,2 \\ & \\ \text { Totale loonpremie } & 21,4\end{array}$
Noot: We hebben de volgende vergelijking geschat: $\ln W_{i}=X_{i} \beta+C_{i} a{ }^{\prime} \stackrel{a}{i}_{i}$ waarbij $\ln W_{i}$ de natuurlijke logaritme van het uurloon van individu $i$ is, $X_{i}$ een vector van geobserveerde persoonlijke ka- rakteristieken van individu $i$, zoals scholingsniveau, leeftijd, werkervaring, enzovoort. $C_{i}$ is een matrix voor de verschillende niveaus van belang van computergebruik op het werk. B en á zijn de geschatte parameters, waarbij (exp (á ) - 1) de computerpremie is die is afgedrukt in de tweede kolom van de tabel. $a_{i}$ is een foutterm met de gebruikelijke veronderstellingen. De ver- gelijking is geschat door middel van OLS

Bron: L. Borghans \& B. ter Weel (2000a, Tabel 2)

Volgens dit soort analyses kan een aanzienlijk deel van de toename in de inkomensverschillen worden toegeschreven aan de opkomst van de computer. De oplossing lijkt dan ook voor de hand te liggen. Het onderwijs zal zich veel meer moeten richten op computervaardigheden. Hiermee wordt voorzien in een alsmaar toenemende vraag van werkgevers naar mensen met adequate computervaardigheden en wordt een verder toenemende loonongelijkheid voorkomen. Deze analyse weerspiegelt duidelijk de visie op computers die tegenwoordig ook onder de bevolking en in het beleid dominant lijkt te zijn. Veel mensen volgen computercursusjes om Windows, tekstverwerkingsprogramma's of het Internet onder de knie te krijgen uit een angst er straks niet meer bij te horen. Men koopt veelal een computer, omdat de kinderen dan vertrouwd raken met deze technologie. Ook een aantal beleidsmaatregelen lijken gebaseerd te zijn op de veronderstelling dat alle jongeren met voldoende computervaardigheden de arbeidsmarkt zullen moeten betreden, omdat anders een onoverbrugbare achterstand dreigt en dientengevolge een tweedeling in de samenleving ontstaat. Uit recent onderzoek komt echter naar voren dat deze gedachtegang onjuist is. Vanuit uiteenlopende invalshoeken worden onderzoeksresultaten gevonden die niet passen in het raamwerk van Krueger. We bespreken hier zeven puzzelstukjes, die het beeld dat computervaardigheden zo belangrijk zijn tegenspreken. 


\section{Grootste premie voor e-mail en tekstverwerken}

Wanneer de resultaten van Krueger goed worden beschouwd, blijkt dat de hoogste computerpremie gaat naar computertaken als e-mailen en tekstverwerken. Dit zijn nu niet bepaald vaardigheden die slechts gegeven zijn aan de hoger opgeleiden. Verrassend genoeg worden taken die worden uitgevoerd door computerprogrammeurs en specialistisch personeel, zoals programmeren en het ontwerpen van software, beloond met een minder hoge computerpremie dan simpele taken, zoals e-mailen.

In Tabel 3 wordt de computerpremie in het Verenigd Koninkrijk uitgesplitst naar vier niveaus van de geavanceerdheid van het computergebruik. Bij deze opsplitsing blijkt een toenemende geavanceerdheid weliswaar tot een hogere premie te leiden, maar blijkt ook dat zelfs de meest eenvoudige computertaken, zoals het printen van een kassabon, een loonpremie oplevert van maar liefst $12,2 \%$. Het is moeilijk in te zien dat de vaardigheid om een moderne kassa in plaats van een oude kassa te bedienen meer dan $10 \%$ extra loon rechtvaardigt. Daarnaast zijn ook de computerpremies voor het gematigd gebruik van computers erg hoog. Gematigd gebruik betreft met name tekstverwerking en het gebruik van spreadsheets. Vanuit het gezichtspunt dat de computerpremie een afspiegeling vormt van de waarde van de desbetreffende vaardigheid, lijkt er dus iets mis te zijn met deze loonpremies.

Tabel 3

Computerpremie in het Verenigd Koninkrijk in 1997 gerelateerd aan de geavanceerdheid van computergebruik

Geavanceerd

Computerpremie (\%)

$\begin{array}{lll}\text { Geavanceerd: } & \text { om te programmeren } & 47,1 \\ \text { Complex: } & \text { voor het analyseren van data en } & 34,4 \\ \text { Gematigd: } & \begin{array}{l}\text { heot maken van ontwerpen } \\ \text { sheets of e-mail }\end{array} & 29,2 \\ \text { Eenvoudig: } & \begin{array}{l}\text { recht toe recht aan, zoals voor } \\ \text { het uitprinten van een bonnetje } \\ \text { op een kassa }\end{array} & 12,2 \\ & \end{array}$

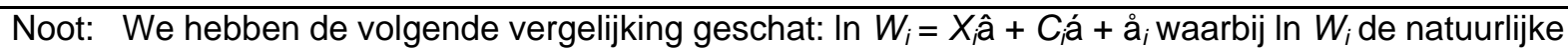 logaritme van het uurloon van individu $i$ is, $X_{i}$ een vector van geobserveerde persoonlijke ka- rakteristieken van individu $i$, zoals scholingsniveau, leeftijd, werkervaring, enzovoort. $C_{i}$ is een matrix voor de verschillende niveaus van geavanceerdheid van computergebruik op het werk. â en á zijn de geschatte parameters, waarbij (exp ( á) -1) de computerpremie is die is afge- drukt in de tweede kolom van de tabel. $\AA_{i}$ is een foutterm met de gebruikelijke veronderstellin- gen. De vergelijking is geschat door middel van OLS
Bron: L. Borghans \& B. ter Weel (2000a, Tabel 2)

\section{Veel laag en middelbaar geschoolden gebruiken de computer}

Het grootste gedeelte van het gebruik van computers heeft betrekking op e-mail en tekstverwerking. Dit is niet bepaald het type specialistische kennis dat slechts voorhanden zou zijn bij hoger opgeleiden. Daarnaast zijn er ook veel laag en middelbaar geschoolden die 
gebruik maken van de computer. Bresnahan (1999) en Handel (1999) laten zien dat het daarom niet aannemelijk is dat 'skill-biased technical change' wordt veroorzaakt doordat hooggeschoolden nodig zijn om de computer te bedienen. Met name veel secretaresses en typisten maken intensief gebruik van PC's. Dit lijkt er niet op te wijzen dat het gebruik van nieuwe technologie met name technische vaardigheden vereist.

\section{Leidt computergebruik wel tot een hoger loon?}

Een aantal onderzoekers interpreteert de computerpremie van Krueger als een aanwijzing voor het feit dat de introductie van computers op de werkplek het loon verhoogt. De computer wordt beschouwd als een 'treatment'. Een werknemers die een computer krijgt, ziet zijn loon omhoog gaan, terwijl een identieke werknemer uit een denkbeeldige controlegroep die de computer niet krijgt deze salarisverhoging niet zal krijgen. De gedachtegang is dat de computer de productiviteit verhoogt en dat de werkgever vervolgens deze productiviteitsverhoging in het salaris tot uiting zal laten komen. Als verondersteld wordt dat er op de arbeidsmarkt sprake is van concurrentie dan is het echter niet duidelijk waarom mensen met gelijke capaciteiten niet ook een gelijke beloning zullen krijgen. Er is met andere woorden geen reden voor de werkgever om de toegenomen productiviteit ook door te geven aan de werknemer.

Het ligt daarom meer voor de hand om er van uit te gaan dat met name degenen die over goede computervaardigheden beschikken, worden geselecteerd voor de banen waar computers worden geïntroduceerd. Als computervaardigheden door de opkomst van ICT aan belang winnen, valt echter te verwachten dat deze selecte groep een snellere toename in het loon kan verwachten dan de groep werknemers die over minder computervaardigheden beschikt. Chennells \& Van Reenen (1998) en Entorf, Gollac \& Kramarz (1999) onderzoeken daarom een panel van werknemers die tijdens de onderzoeksperiode een computer zijn gaan gebruiken. Hun bevindingen zijn dat werknemers die een computer gaan gebruiken tijdens de onderzochte periode geen significant hoger loon ontvangen dan de groep die de computer niet is gaan gebruiken. Entorf, Gollac \& Kramarz concluderen hieruit dat werknemers met het grootste - niet waarneembare - computertalent door het bedrijf worden geselecteerd om een computer te gebruiken. Haisken-DeNew \& Schmidt (1999) vinden vergelijkbare resultaten voor computergebruik in een Duits panel. Bell (1996) vindt daarentegen wel een aanzienlijke loonstoename voor computergebruik. Zijn onderzoek heeft echter betrekking op een veel langere periode dan de eerdergenoemde analyses. Een studie van Entorf \& Kramarz (1997) laat zien dat werknemers die een computer gebruiken, jaarlijks ongeveer $1 \%$ meer salarisgroei doormaken. Zij interpreteren dit als de marktwaarde voor de computerervaring die mensen hebben opgedaan. Het is echter de vraag of deze interpretatie juist is. De bevindingen zouden er immers ook op kunnen wijzen dat niet het computergebruik van iedere afzonderlijke werknemer, maar juist de toenemende marktwaarde van deze groep als geheel de lonen beïnvloedt. 
Bedrijven met veel computergebruik betalen ook mensen die de computers niet gebruiken hogere salarissen

Het idee dat de computerpremie vooral moet worden gezien als een waardering van individuele computervaardigheden betekent dat alleen degenen die de computer ook daadwerkelijk gebruiken een hoger salaris zullen krijgen. Studies van Doms, Dunne \& Troske (1997) en Dunne, Foster, Haltiwanger \& Troske (2000) laten echter zien dat de computerpremie geen individueel, maar een bedrijfseffect is. Zij hebben gevonden dat bedrijven die met geavanceerde technologie zoals computers werken hun werknemers meer betalen. Het maakt hierbij niet uit of een werknemer de computer zelf gebruikt of niet, hij krijgt toch een loonpremie. Opmerkelijk is verder dat in het bijzonder managers die zelf niet de meest geavanceerde technologie gebruiken de hoogste loonpremie ontvangen.

\section{Mensen met computervaardigheden gebruiken lang niet altijd een computer}

Als computervaardigheden van toenemend belang zijn op de arbeidsmarkt en zij door het toenemende gebruik van computers een schaarse factor zijn geworden, zullen werkgevers proberen iedereen die over deze computervaardigheden beschikt ook in te zetten in werk waarvoor dit belangrijk is. DiNardo \& Pischke (1996) laten echter voor Duitsland zien dat lang niet iedereen met computervaardigheden ook werk heeft waarbij de computer wordt gebruikt. Omgekeerd blijkt een redelijk groot aantal mensen te werken in banen waarin de computer wel wordt gebruikt, terwijl ze geen computervaardigheden bezitten.

Ook komt het regelmatig voor dat mensen die een computer op hun werk gebruiken, overstappen naar een baan waarbij de computer niet wordt gebruikt. Tabel 4 laat zien dat in het Verenigd Koninkrijk 4\% van de werknemers in 1992 een computer gebruikte, maar dat in 1997 niet meer deed. Dit betekent dat tegen de sterke stroom van het toenemende computergebruik in ongeveer één op de tien werknemers juist ophoudt de computer te gebruiken.

Tabel 4

Relatie tussen computergebruik in 1992 en 1997

Geen computer in 1997 (\%) Wel een computer in 1997 (\%)

Geen computer in 1992

Wel een computer in 1992

$27 \quad 26$

$4 \quad 44$

Noot: De som van de percentages telt op tot $100 \%$

Bron: Skills Survey of the Employed British Workforce

Het gebruik van pennen levert ook een premie op

DiNardo \& Pischke (1997) bekijken Krueger's resultaten kritisch door na te gaan of alleen computergebruik opmerkelijke salarisverschillen kan verklaren. Zij bekijken daarom of het gebruik van andere attributen zoals onder andere een pen, een rekenmachine, een telefoon en het feit of iemand tijdens zijn of haar werk zit of staat, loonsverschillen kan verklaren. Zij 
vinden naast de computerpremie, een qua omvang vergelijkbare premie voor het gebruik van pennen. Uit deze resultaten concluderen ze dat Krueger's computerpremie waarschijnlijk geen adequate maatstaf is voor het belang van computervaardigheden.

\section{Beloning blijkt niet gerelateerd te zijn aan computervaardigheden}

De zes typen onderzoeksresultaten die hierboven zijn besproken, roepen allemaal twijfels op over de vraag of de computerpremie wel moet worden geïnterpreteerd als een beloning voor computervaardigheden. De vraagtekens die zij plaatsen bij het vermeende belang van computervaardigheden zijn echter steeds gebaseerd op indirect bewijs. Deze onderzoeksresultaten maken duidelijk dat er behoefte is aan een maatstaf voor computervaardigheden om zo het belang van computervaardigheden voor de arbeidsmarkt direct te kunnen analyseren. Deze behoefte is onderkend in de Britse Skills Survey of the Employed British Workforce. In deze enquête werd respondenten voor het eerst rechtstreeks naar het niveau van hun computervaardigheden gevraagd ${ }^{10}$. De maat voor computervaardigheden loopt van zeer hoge tot zeer lage computervaardigheden. De gegevens zijn alleen beschikbaar over mensen die de computer ook daadwerkelijk gebruiken.

In Tabel 5 wordt per vaardighedenniveau de loonpremie gegeven. Afgezien van de groep met zeer lage computervaardigheden blijkt iedereen vrijwel dezelfde computerpremie te ontvangen. Verrassend is het resultaat dat mensen met gemiddelde computervaardigheden de hoogste computerpremie ontvangen. Hoewel de resultaten van de hoogste vier categorieën vaardigheden statistisch niet onderscheidbaar zijn, is dit resultaat erg opmerkelijk. Het lijkt erop te wijzen dat computervaardigheden niet erg belangrijk zijn voor het loon dat iemand ontvangt, zolang een werknemer maar enige vaardigheden heeft. De vraag 'hebben we computervaardigheden nodig om een computer te bedienen?' lijkt dan ook gegrond. Alleen de groep mensen met zeer lage computervaardigheden blijkt een veel lagere loonpremie van $8,5 \%$ te ontvangen. Deze groep mensen, die zegt nauwelijks adequaat met een computer te kunnen werken, is overigens erg klein. Kennelijk is het volledig ontbreken van computervaardigheden toch nog belemmerend voor het werk. Opmerkelijk is wel dat deze men-

10. In een enquête ontstaat snel verwarring tussen computervaardigheden, computergebruik en de vraag of de respondent weet wat een computer doet. In de Skills Survey of the Employed British Workforce is daarom met grote zorgvuldigheid een vraag voor computervaardigheden ontwikkeld. Wij kennen drie andere studies die een directe, maar minder adequate maatstaf voor computervaardigheden gebruiken. De eerste is Hamilton (1997). Hij gebruikt computervariabelen uit de High School and Beyond Survey van 1986 die impliceren of een individu ooit software heeft gebruikt of een computertaal heeft gebruikt om te programmeren. Zijn bevindingen zijn dat personen die deze vragen positief beantwoorden een computerpremie van ongeveer $8 \%$ ontvangen. Een tweede studie is uitgevoerd door Bell (1996). Bell's analyse laat zien dat computertalent de loonpremie niet kan verklaren. De derde studie die direct de invloed van computervaardigheden onderzoekt is DiNardo \& Pischke (1996). Zij vinden een hoge opbrengst voor computervaardigheden in Duitsland, maar Borghans \& Ter Weel (2000b) laten zien dat dit het gevolg is van een onjuiste econometrische specificatie. Na zorgvuldige analyse blijkt dat ook op basis van deze maatstaf computervaardigheden niet belangrijk zijn. 
sen desondanks nog altijd aanzienlijk meer verdienen dan vergelijkbare personen die geen computer op het werk gebruiken.

Tabel 5

Computerpremie voor vijf niveaus van computervaardigheden

Zeer hoog

Hoog

Gemiddeld

Laag

Zeer laag
22,9

23,2

25,1

22,1

8,5

Noot: We hebben de volgende vergelijking geschat: $\ln W_{i}=X_{i} \hat{a}+C_{i} a ́$ + å ${ }_{i}$ waarbij $\ln W_{i}$ de natuurlijke logaritme van het uurloon van individu $i$ is, $X_{i}$ een vector van geobserveerde persoonlijke karakteristieken van individu $i$, zoals scholingsniveau, leeftijd, werkervaring, enzovoort. $C_{i}$ is een matrix van verschillende niveaus van computervaardigheden. â en á zijn de geschatte parameters, waarbij (exp (á) - 1) de premie is voor computervaardigheden, die is afgedrukt in de tweede kolom van de tabel. $a_{i}$ is een foutterm met de gebruikelijke veronderstellingen. De vergelijking is geschat door middel van OLS

Bron: L. Borghans \& B. ter Weel (2000a, Tabel 2)

Deze zeven moeilijk inpasbare puzzelstukjes hebben een aantal (arbeidsmarkt)economen aan het twijfelen gebracht over de juistheid van het idee dat het bedienen van computers bijzondere en waardevolle vaardigheden vergt. Als alternatieve verklaring voor de computerpremie en voor het feit dat met name hoger opgeleiden computers gebruiken, wordt gewezen op de mogelijkheid van zogeheten complementaire vaardigheden (Levy \& Murnane, 1996). Levy, Beamish, Murnane \& Autor (1999) stellen een raamwerk voor waarin vaardigheden worden geclassificeerd op basis van wat computers en wat mensen het beste kunnen. Het idee is dat een computer vooral goed is in kille berekeningen. Om volop de mogelijkheden van een computer te benutten, moet de gebruiker beschikken over vaardigheden waarover een computer juist niet beschikt. Deze complementaire vaardigheden kunnen variëren van creativiteit van de ontwerper, improvisatie, analyse en communicatieve vermogens van de manager, tot de vriendelijke stem van de werknemer in het call center of de hulpvaardigheid van de verkoper. Het kan hierbij dus zowel gaan om vaardigheden die vooral met hoger opgeleiden worden geassocieerd, maar ook om vaardigheden die ook bij middelbaar en lager opgeleiden voorhanden zijn.

Het hoger loon dat werkenden die een computer gebruiken krijgen, is dan uiting van meer verantwoordelijkheid, adaptatievermogen en ontwikkelingscapaciteit. Met andere woorden, van 'skill-biased technical change' als concept, dat een louter technische complementariteit aangeeft, waarbij de voor het gebruik van nieuwe technologie benodigde kwalificaties als het ware in het instructieboekje staan, is vanuit deze optiek geen sprake meer. Vanuit de complementariteitsgedachte faciliteert de computer de manier waarop mensen organiseren en communiceren. 'Soft skills' zijn vanuit deze optiek dan ook van toenemend belang en 'skillbiased technical change' reflecteert meer een organisatorische ontwikkeling: Gebruik van de nieuwe technologie vereist niet zozeer nieuwe technische vaardigheden, maar ook en vooral 
organisatorisch vermogen, waarbij de nieuwe technologie-mogelijkheden worden benut voor het nemen van autonome beslissingen en verantwoordelijkheden. Dit zou betekenen dat er bij de kwalificaties die worden gevraagd door werkgevers, een geleidelijke verschuiving plaatsvindt die spoort met de overgang in Westerse economieën van een op vrij Tayloristische wijze georganiseerde industriële en diensteneconomie naar een kenniseconomie. In deze nieuwe economie zouden dan, naast specifieke technische vaardigheden, nu ook bredere communicatie-, beslissings- en verantwoordelijkheidsvaardigheden, snel aan belang winnen (zie bijvoorbeeld Murnane, Willett \& Levy, 1995; Lindbeck \& Snower, 2000).

In tegenstelling tot een computer is het volstrekt evident dat voor het gebruik van een mobiele telefoon geen bijzondere vaardigheden vereist zijn. Omdat vanuit de complementariteitsgedachte de vraag naar vaardigheden niet meer direct is gekoppeld aan de techniek, is het ook niet meer essentieel dat verschuivingen in de vraag naar hoger opgeleiden worden verklaard door de opkomst van de computer alleen. Ook recente technologische doorbraken op het gebied van communicatietechnologie (onder andere internet, mobiele telefonie) hebben een nieuwe impuls gegeven aan de spreiding en het gebruik van ICT in alle sectoren van de economie en hebben aanleiding gegeven tot nieuwe vormen van interactie en netwerkgebruik van computers. Naarmate deze technologie goedkoper wordt, zou dan opnieuw de beschikbaarheid van hooggekwalificeerd, maar ook en vooral flexibel personeel, dat deze kennis kan vertalen en gebruiken, binnen de contouren van de organisatie essentieel worden. Meer nog dan in het geval van computers kan bij informatietechnologie worden verwacht dat communicatievaardigheden de essentiële nieuwe scholingsvaardigheid zal zijn, die complementair is aan het gebruik van ICT (zie bijvoorbeeld Soete \& Ter Weel, 1999).

Het onderzoek naar de consequenties van het toenemende gebruik van computers en ICT richt zich dan ook meer en meer op de vraag welke vaardigheden complementair zijn aan het gebruik van moderne ICT. De zoektocht is echter nog in volle gang en harde bevindingen zijn er nog niet. Borghans \& Ter Weel (2000a) laten wel zien welke vaardigheden de hoogste waarde hebben voor mensen die de computer op een gegeven niveau van geavanceerdheid gebruiken. Dit hoeft echter nog niet te betekenen dat de waarde van deze vaardigheden ook is toegenomen als gevolg van de introductie van de computer. Tabel 6 laat deze vaardigheden zien. Voor elk niveau van computergebruik (geavanceerd, complex, gematigd en eenvoudig) hebben we uit een groep van 45 gekeken naar de vaardigheden die de hoogste loonpremie opleveren ${ }^{11}$.

Het blijkt dat computervaardigheden niet van belang zijn. Voor het geavanceerde niveau van computergebruik is de belangrijkste vaardigheid het grondig analyseren van complexe problemen en het achterhalen van de oorzaken van problemen en fouten. Dat deze vaardigheden van belang zijn wanneer de computer op een geavanceerde wijze wordt gebruikt ligt voor de hand. Eén van de belangrijkste eigenschappen van een programmeur is uiteraard het achterhalen van (programmeer)fouten en het opzetten, analyseren en bouwen van computersystemen. Het uiteindelijk invoeren in de computer en het schrijven in programmeertaal

11. Ashton, Davies, Felstead \& Green (1999) geven een overzicht van deze vaardigheden en de constructie naar aanleiding van de enquête. 
blijkt van minder belang te zijn. Het werken in teamverband en kennis met betrekking tot de werking van de organisatie zijn de belangrijkste vaardigheden wanneer een werknemer de computer op een complexe manier gebruikt. Het op een complexe wijze gebruiken van computers betekent dat een werknemer de computer gebruikt voor het analyseren van data en het maken van ontwerpen. Dit zijn bijvoorbeeld mensen op de marketingafdeling van een groot bedrijf die strategieën uitstippelen aan de hand van verkoopgegevens. Ook kunnen dit ontwerpers van reclamecampagnes of billboards zijn, die met complexe teken- en grafische programma's een ontwerp maken. Wanneer de computer slechts wordt gebruikt op een gematigde wijze, zijn het grondig analyseren van complexe problemen en het maken van speeches en presentaties de meest belangrijke vaardigheden. Het gematigde niveau van computergebruik betekent dat de computer wordt gebruikt voor tekstverwerken, het werken met eenvoudige spreadsheet programma's zoals Excel en Lotus, en het lezen en versturen van e-mails. Het gaat hierbij om een gevarieerde groep mensen, uiteenlopend van managers tot secretaresses. Dit verklaart dat zowel het grondig analyseren van complexe problemen als het maken van speeches en presentaties belangrijke vaardigheden zijn. Tenslotte is het schrijven van korte documenten en het grondig analyseren van complexe problemen van belang wanneer de computer voor simpele taken wordt gebruikt.

Tabel 6

Twee vaardigheden die de meeste waarde hebben voor verschillende niveaus van computergebruik

Niveau van Computergebruik

$\begin{array}{llll}\text { Geavanceerd } & \text { Complex } & \text { Gematigd } & \text { Eenvoudig }\end{array}$

Grondig analyseren van Het werken in teamvercomplexe problemen band

Het achterhalen van oorzaken van problemen en fouten
Kennis met betrekking tot de werking van de organisatie
Grondig analyseren van complexe problemen

schrijven van korte

Het maken van speeches en presentaties documenten

Grondig analyseren van complex problemen

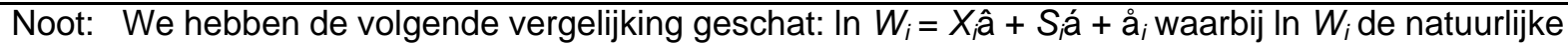
logaritme van het uurloon van individu $i$ is, $X_{i}$ een vector van geobserveerde persoonlijke karakteristieken van individu $i$, zoals scholingsniveau, leeftijd, werkervaring, enzovoort. $S_{i}$ is een matrix van de verschillende niveaus van 45 verschillende vaardigheden. Ashton, Davies, Felstead \& Green (1999) geven een overzicht van deze 45 vaardigheden. â en á zijn de geschatte parameters. $\stackrel{a}{i}_{i}$ is een foutterm met de gebruikelijke veronderstellingen. De vergelijking is geschat door middel van OLS voor elk niveau van computergebruik. De belangrijkste vaardigheden voor elk niveau van computergebruik zijn afgedrukt

Bron: L. Borghans \& B. ter Weel (2000a, Tabel 4)

Het blijft overigens moeilijk om op basis van de complementariteitsgedachte alle onderzoeksresultaten te verklaren die in deze paragraaf zijn besproken. Als complementaire vaardigheden de computerpremie van Krueger moeten verklaren, kan men zich afvragen of computergebruik niet toch tot een hoger loon zou moeten leiden, of ook mensen die de computer niet gebruiken in een bedrijf met veel computergebruik hiervoor moeten worden 
beloond, waarom mensen stoppen met computergebruik en hoe het mogelijk is dat ook pennen een premie met zich meebrengen. Het belangrijkste probleem is vooralsnog dat onderzoek niet duidelijk de complementaire vaardigheden heeft aan kunnen wijzen die belangrijk genoeg zijn om de toch zeer hoge computerpremie van Krueger te verklaren.

Om een beter begrip te krijgen van de betekenis van de opkomst van de computer voor werkgelegenheid en om beter te begrijpen hoe de computer van invloed zal zijn op de kennis en vaardigheden die van belang zijn voor de arbeidsmarkt is het dus belangrijk om in meer detail te onderzoeken hoe een computer wordt ingezet en op welke wijze de werkzaamheden van werknemers en de organisatie van het bedrijf zich aanpassen. Hoewel nog maar weinig bekend is over dit proces zullen we in de volgende paragraaf ons licht laten schijnen op de mogelijke betekenis van computers voor het werk, om daarmee de empirische bevindingen uit deze paragraaf in het juiste daglicht te kunnen plaatsen. Door concreet te analyseren welke implicaties ICT heeft voor de werkzaamheden van mensen en in te gaan op de interactie tussen mens en machine ontstaat een nieuw kader waarin de meeste onderzoeksbevindingen goed passen.

\section{De impact van ICT op de werkplek}

Een essentieel kenmerk van ICT is dat deze techniek mensen ondersteunt in hun werkzaamheden. De apparaten bevinden zich in de buurt van iemands werkplek. De PC met internettoegang staat op het bureau, de mobiele telefoon zit in de tas en de computerkassa staat op de toonbank. Aan de ene kant neemt ICT dus niet al het werk over - zoals gevreesd werd in Chaplin's Modern Times en de jaren zestig en zeventig - waardoor de desbetreffende werknemer niets meer te doen heeft. Aan de andere kant wordt ook niet al het werk door middel van de nieuwe technologie uitgevoerd. Wanneer wij deze paper schrijven werken we weliswaar een groot deel van de tijd met onze PC's, maar de samenwerking met die computer blijft beperkt. De computer houdt bij welke woorden we reeds aan het verhaal hebben toegevoegd en is behulpzaam bij het schuiven met alinea's, het corrigeren van de spelling en het printen of e-mailen van de tekst naar elkaar of de redactie. Een groot deel van het werk - nadenken over de boodschap en de inhoud van de paper - blijft echter werk dat we zelf doen en waartoe de computer niet in staat is. Vandaar dat het onjuist is te veronderstellen dat de computer al het werk overneemt en dat de taak van de mens is gereduceerd tot het bedienen van de juiste knoppen, de juiste tapes aan de computer hangen en wellicht zelfs een losgeschoten draadje weer vast te solderen om op die manier zorg te dragen voor een adequate uitvoering van het werk door de computer, zoals in Figuur 2.

Om na te gaan wat de invloed van ICT is op de manier waarop wij werken, is het interessant dit eens grondig onder de loep te nemen. Borghans en Ter Weel (2000c) veronderstellen dat een werknemer voordat hij bepaalde ICT ter beschikking krijgt twee soorten werkzaamheden uitvoert - taak 1 en taak 2 . Het is interessant de consequenties van de introductie van een computer in een dergelijke situatie te analyseren. Mogelijk, en zelfs waarschijnlijk, zijn deze taken zeer vervlochten, maar van belang is louter dat ICT taak 1 ondersteunt, maar niet in staat is taak 2 te ondersteunen. Hoewel de taken qua aard en vereiste vaardigheden sterk 
van elkaar kunnen verschillen, is het door de samenhang van de werkzaamheden niet mogelijk de taken uit te splitsen in twee verschillende banen, waardoor voor beide functies iemand met de meest geschikte kwalificaties zou kunnen worden aangenomen.

In dit eenvoudige raamwerk zijn twee vragen van centraal belang. De eerste vraag is uiteraard in welke situaties en wanneer bedrijven zullen besluiten om ICT aan te schaffen voor een bepaalde werkplek. De tweede vraag is wat de veranderingen van het werk zijn als ICT daadwerkelijk ten tonele verschijnt en wordt geïm plementeerd. Om deze twee vragen nader te analyseren, kan worden gekeken naar verschillende invloeden van ICT op werk. Bijvoorbeeld welke invloed ICT heeft op de productiviteit, hoe dit de vraag naar werkenden in deze functie zal veranderen, wat er zal gebeuren met het loon, maar ook of het gewenste opleidingsniveau voor deze functie zal veranderen, wat de invloed zal zijn op de waarde van verschillende vaardigheden, of het product zal worden aangepast en hoe de wijze waarop binnen een bedrijf wordt gewerkt zal veranderen.

\subsection{Wie gebruikt ICT?}

Allereerst gaan we in op de vraag onder welke omstandigheden zal worden besloten ICT aan te schaffen om het werk te ondersteunen. Als we aannemen dat ICT alleen zal worden ingevoerd als het rendabel is voor het bedrijf, dan is het bij deze beslissing van belang of (i) de efficiëntie van het werk door ICT wordt vergroot en of (ii) de baten hiervan groot genoeg zijn om de kosten van de desbetreffende apparatuur te rechtvaardigen. Verderop in dit preadvies bespreken we wat er gebeurt als de ICT-ontwikkeling zich voortzet. Voor de inzichtelijkheid is het functioneel beide aspecten van de kosten-baten-afweging te scheiden. In de verdere ontwikkeling van ICT kan immers (i) de effectiviteit van de apparaten of de bijbehorende software en andere applicaties verder toenemen, maar kunnen ook (ii) de kosten van het gebruik dalen.

De efficiëntie van het productieproces zal uiteraard groter worden wanneer de taken die iemand heeft dankzij ICT sneller kunnen worden uitgevoerd. Deze tijdwinst kan betrekking hebben op het werk dat wordt geautomatiseerd en op het werk dat niet door ICT wordt overgenomen. In het geval dat taak 1 wordt geautomatiseerd, zal de tijd die het kost om deze taak zelf uit te voeren worden vervangen door de tijd die nodig is om de computer adequaat te bedienen. De grootste winst valt dus te boeken wanneer taak 1 goed te automatiseren is en de gebruiker efficiënt met de desbetreffende ICT weet om te gaan. De werkzaamheden die niet (kunnen) worden geautomatiseerd (taak 2) blijven in principe evenveel tijd in beslag nemen. Het is echter ook denkbaar dat dankzij de introductie van ICT taak 2 ook efficiënter kan worden uitgevoerd. Dit weerspiegelt de mogelijkheid dat technologie en arbeid complementair zijn. Door de mogelijkheden van ICT optimaal te benutten in taak 1 kan ook de complementaire taak 2 efficiënter worden uitgevoerd. De accountant is een goed voorbeeld van een beroep waarvan één taak is geautomatiseerd. De huidige accountant hoeft niet meer te hoofdrekenen of een kladblok te gebruiken om de boeken van een bedrijf te controleren. $\mathrm{Hij}$ gebruikt een computer met spreadsheetprogramma om de cijfers op te tellen, te delen et cetera. De accountant kan zich nu geheel toeleggen op het analyseren en controleren (met behulp van de computer) van de juistheid van de cijfers en sneller fouten en fraude opspo- 
ren als de cijfers niet kloppen. Als de complementariteit tussen de twee taken groot is, zal ook taak 2 (de analyse) in minder tijd kunnen worden uitgevoerd.

Er zijn drie invalshoeken met betrekking tot de werkgelegenheidseffecten van computergebruik die extreme gevallen van dit denkkader zijn. In het beeld waarbij wordt verwacht dat de computer het werk van de mens zal overnemen, bestaat het werk alleen uit de automatiseerbare taak 1 en is weinig of geen tijd nodig de computer te bedienen. Omdat met name laaggeschoolden dit soort werk doen, zijn zij als eersten het slachtoffer. Een tweede visie stelt dat het werk alleen uit de automatiseerbare taak 1 bestaat, maar dat computervaardigheden zó belangrijk zijn dat het aan de praat houden van de computer veel tijd en specifieke vaardigheden vergt. Omdat wordt verwacht dat met name hooggeschoolden over deze vaardigheden beschikken, zullen zij dit computerwerk gaan uitvoeren. Tenslotte bestaat een beeld waarin complementaire vaardigheden de waarde van computergebruik bepalen. $\mathrm{Nu}$ is de automatiseerbare taak juist marginaal en valt dus niet veel tijdwinst te boeken. Het voordeel moet dan worden behaald door middel van toegenomen efficiëntie van de complementaire taken.

Het is interessant te zien dat ook wanneer computervaardigheden niet van belang zijn, en geen complementariteitsvoordelen te behalen zijn, de introductie van ICT toch tijdwinst kan opleveren, zonder dat het werk volledig verdwijnt. In dit zeer eenvoudige geval hoeft de werknemer immers alleen nog maar taak 2 uit te voeren en neemt de ICT taak 1 volledig van hem over.

Een bedrijf zal echter alleen overgaan tot aanschaf van de apparatuur als de kosten van deze ICT opwegen tegen de tijdwinst die kan worden geboekt. Tijdwinst in het productieproces vertaalt zich in een productiviteitsstijging en betekent uiteraard besparing op loonkosten. Het is dus aantrekkelijk ICT aan te schaffen als de kosten van het apparaat lager zijn dan het loon dat moet worden terugverdiend. Naast de omvang van de tijdwinst zal het loon van de betrokken medewerker bepalen of ICT zichzelf zal terugverdienen. Dit blijkt zelfs op te gaan als het loon geen goede afspiegeling vormt van de productiviteit. Als door allerlei institutionele factoren het loon in een bepaalde beroepsgroep relatief hoog is, vergeleken met andere beroepsgroepen zal, ceterus paribus, de computer hier sneller emplooi vinden. Als een beroepsgroep veel minder verdient dan op grond van de productiviteit mag worden verwacht, zal juist minder snel in ICT worden geïnvesteerd. Het mechanisme dat bepaalt of en wanneer een computer wordt geïntroduceerd op de werkplek loopt dus via het loon dat een individu verdient en niet zozeer via de computervaardigheden of complementaire vaardigheden waarover deze werknemer beschikt.

Deze eenvoudige constatering zet de Krueger-vergelijking op zijn kop. Zelfs als we corrigeren voor persoonlijke eigenschappen en baankenmerken, verklaren schommelingen in het loon de kans dat iemand een computer heeft. Het is dus niet zo dat hooggeschoolden eerder een computer krijgen, maar hoogbetaalden ontvangen een dergelijk apparaat als eersten. Hoe onbelangrijker het desbetreffende apparaat is voor het werk, des te meer loonverschil nodig is om de aanschaf rendabel te maken. Juist daarom hebben relatief onbelangrijke zaken, zoals e-mailen en tekstverwerken, een grote impact op het loon. Als een mana- 
ger en zijn assistent evenveel tijd kwijt zijn aan dezelfde taak en zij hier beide even handig in zijn, dan zullen de baten van automatisering bij de manager makkelijker de kosten voor de automatisering compenseren. De manager verdient immers veel meer dan zijn assistent, waardoor zijn tijdsbesparing het bedrijf meer zal opleveren.

Zoals reeds is opgemerkt, doet het er hierbij niet toe of het loon de productiviteit weerspiegelt of niet. Productiviteitsverschillen kunnen echter ontstaan doordat iemand in staat is producten van grotere waarde of een hogere kwaliteit te produceren, maar kunnen ook ontstaan doordat de ene persoon hetzelfde werk sneller weet uit te voeren dan een ander. Juist als een hoger loon duidt op een grotere snelheid van werken, zal minder snel tot aanschaf van ICT worden overgegaan. Voor een snelle werker is immers minder tijdwinst te boeken als de computer zijn werk overneemt.

Uit deze redenering volgt dat wanneer de kosten van computergebruik verder zullen dalen, de introductie van ICT voor meer functies rendabel wordt. Als de kosten tot nul zouden reduceren zou in alle functies waar ICT tijdwinst oplevert tot introductie worden overgegaan. Als daarnaast de toepassingsmogelijkheden en de efficiëntie van ICT verder zal toenemen, zal ook de groep functies waarvoor een zinvolle toepassing mogelijk is stijgen. Als de kosten voldoende dalen en de toepassingsgebieden verder toenemen, zal uiteindelijk wellicht in vrijwel iedere functie met ICT worden gewerkt.

Dit betekent dus ook dat de kostenontwikkeling van ICT-gebruik cruciaal is voor de introductie van ICT op het werk. Juist omdat technische infrastructuur voor ICT omvangrijke positieve externe effecten zal hebben, kan het economisch beleid om de prijsontwikkeling van deze infrastructuur in goede banen te leiden, grote implicaties hebben voor productiviteitsstijgingen op de arbeidsmarkt. Ook de beschikbaarheid van software en digitale informatie bepaalt de kosten van computergebruik. Doordat het hierbij gaat om gecompliceerde markten waarbij de marginale kosten van reproductie vrijwel nul zijn maar de ontwikkelingskosten omvangrijk kunnen zijn, kunnen snel marktverstoringen ontstaan (zie bijvoorbeeld Borghans \& Groot, 1997, 1998). Als oude regelgeving op het gebied van eigendomsrechten en mededinging niet zijn toegesneden op deze nieuwe problematiek, kunnen te hoge kosten de introductie van nieuwe ICT-applicaties afremmen.

Voor een groot deel zullen de kosten van de introductie van ICT niet afhangen van het aantal medewerkers in een bedrijf of afdeling dat gebruik maakt van de techniek, maar zullen veel kosten voortkomen uit de ontwikkeling en implementatie voor het bedrijf of de afdeling als geheel. Omdat binnen een afdeling moet kunnen worden samengewerkt, zal het vaak ook moeilijk zijn om de ene medewerker wel en de andere medewerker geen gebruik van computer- of communicatiesystemen te laten maken. Het gevolg hiervan is dat ten dele niet het loon zelf, maar de loonsom van de afdeling waar iemand werkt, bepalend kan zijn voor het al dan niet gebruiken van ICT. 


\subsection{Productiviteit, vraag en loon}

De introductie van ICT zal leiden tot een productiviteitsstijging. Deze is gelijk aan de relatieve tijdwinst die wordt geboekt in het productieproces als gevolg van het automatiseren van taak 1. Als de totale productie-omvang gelijk blijft, zal de vraag naar werknemers in dit beroep dus afnemen met een zelfde percentage. De productiekosten nemen minder af, omdat tegenover de afnemende loonkosten stijgende kosten voor het gebruik van ICT zullen staan. Naast deze directe reductie in de vraag naar arbeid als gevolg van de productiviteitsstijging zal de verlaagde kostprijs per eenheid product echter leiden tot een toename van de vraag naar het desbetreffende product en daarmee indirect tot een hogere vraag naar de bijbehorende arbeid. Het uiteindelijke effect op de werkgelegenheid hangt af van de omvang van beide effecten. Wanneer de prijselasticiteit van de vraag hoog is, kan een efficiëntieverbetering leiden tot een toename van de vraag naar arbeid en zal een opwaartse druk op de Ionen ontstaan ${ }^{12}$. Als wordt aangenomen dat ICT vooral bij hoger opgeleiden wordt ingevoerd, zal alleen als deze elasticiteit voldoende groot is sprake zijn van 'skill-biased technical change', dat wil zeggen een verbetering van de positie van hoger opgeleiden ten opzichte van de positie van lager opgeleiden. Wanneer bovendien na verloop van tijd de kosten van computergebruik zo laag zijn dat in alle functies waarin tijdwinst te behalen is, ICT wordt geïntroduceerd, kunnen deze vraageffecten net zo goed opt reden bij laaggeschoolde werknemers. Uiteindelijk lijkt het effect van ICT op de vraag naar arbeid via deze route dus ambigu en ligt het niet voor de hand hier de belangrijkste verklaring voor 'skill-biased technical change' te zoeken.

\subsection{Welke vaardigheden zijn belangrijk?}

We hebben dus laten zien dat zelfs wanneer computervaardigheden geen rol spelen en ook geen sprake is van complementariteit, waarbij bepaalde vaardigheden dankzij de computer beter uit de verf komen, de introductie van ICT toch kan worden verklaard en het plausibel is dat werknemers met een hoger loon eerder met ICT te maken krijgen. Ook zonder een expliciete rol voor computervaardigheden en complementaire vaardigheden zal de waarde van verschillende vaardigheden op de arbeidsmarkt gaan verschuiven als gevolg van de introductie en diffusie van ICT. De samenstelling van het werk gaat immers verschuiven, waardoor de vaardigheden die de productiviteit in het werk dat overblijft bevorderen, in belang toenemen, terwijl de vaardigheden die nodig waren voor het werk dat de computer nu doet in belang zullen afnemen.

Hiermee is overigens niet gezegd dat computervaardigheden en complementariteit geen rol kunnen spelen in dit proces. In principe is dit een empirische kwestie en kan alleen gedegen empirisch onderzoek op basis van goede dataverzameling aan het licht brengen hoe het belang van verschillende vaardigheden aan het verschuiven is. Ook hier ontstaat mogelijk 'skill-biased technical change'. Dit zal het geval zijn als met name vaardigheden waar hoger

12. Het gaat hierbij alleen om een partieel effect op het loon. Omdat door ICT de vraag voor allerlei beroepen zal veranderen en loonsveranderingen in de ene deelmarkt van invloed kunnen zijn op andere deelmarkten zijn de uiteindelijke effecten in een algemeen evenwicht moeilijk te overzien. 
opgeleiden over beschikken in waarde toenemen. Uit de voorbeelden die eerder zijn gegeven, lijkt dit echter niet plausibel te zijn. Tot het werk dat moeilijk geautomatiseerd kan worden, behoren immers net zo goed klantvriendelijkheid en geduld, als leidinggevende capaciteiten.

\subsection{Het gevraagde opleidingsniveau}

De opleidings- en kwalificatie-eisen die een werkgever stelt voor een bepaalde functie kunnen worden gezien als een afweging tussen het hogere loon dat moet worden betaald voor een hoger opgeleide en de extra productiviteit die een werknemer in deze functie kan leveren. In een functie waarin een hoger opgeleide niet veel aan de productiviteit toevoegt, vergeleken met een lager gekwalificeerde medewerker, zullen de opleidingseisen daarom niet snel worden verhoogd (zie Borghans \& De Grip, 2000a; 2000b). Het lijkt acceptabel aan te nemen dat een hoger opgeleide vooral productiviteitswinst zal boeken in het deel van de werkzaamheden dat niet goed kan worden geautomatiseerd ${ }^{13}$.

Voordat ICT werd ingevoerd betekende het verhogen van de opleidingseisen ook dat een duur betaalde kracht in taak 1 werk ging doen waarin hij niet beter was dan mensen met minder opleiding. Dit functioneerde als een rem op de kwalificatie-eisen die werden gesteld. $\mathrm{Na}$ de introductie van ICT spelen werkzaamheden als taak 1 geen rol meer. Zelfs als de hoger opgeleide niet behendiger is in het uitvoeren van de gecomputeriseerde taak 1 valt te verwachten dat werkgevers hun opleidingseisen zullen opschroeven, omdat het belang en de waarde van taak 2 toeneemt. Groot \& De Grip (1991) waren één van de eersten die lieten zien dat de introductie van ICT leidt tot hogere opleidingseisen. Door filialen van een grote Nederlandse bank met elkaar te vergelijken, die verschilden in het moment waarop zij de front office en back office automatiseerden, konden zij laten zien dat geautomatiseerde bankfilialen inderdaad hun opleidingseisen verhoogden ${ }^{14}$.

Deze verschuiving van het belang van taken vormt een derde mogelijke oorzaak van 'skill-biased technical change'. Of het nu gaat om een hooggekwalificeerde of een laaggekwalificeerde baan, na de introductie van ICT valt te verwachten dat binnen deze functie de opleidingseisen gradueel zullen stijgen. Binnen iedere functie gaat het dus niet om een omslag van een ongeschoolde naar een academicus, maar geaggregeerd zullen deze vraagverschuivingen de werkgelegenheidsstructuur als geheel veranderen. Het valt te verwachten dat dit effect veel sterker tot 'skill-biased technical change' zal leiden dan de eerdere mogelijke effecten. Verschuivingen in de vraag kunnen immers zowel in het voor- als in het nadeel van hoger opgeleiden werken, terwijl deze verhoging van de opleidingseisen binnen een bepaalde baan vrijwel altijd in dezelfde opwaartse richting werkt.

13. Autor, Levy \& Murnane (2000) geven enkele interessante tegenvoorbeelden van werk dat relatief goed geprogrammeerd kan worden - en dus voor de computer relatief makkelijk is - terwijl bij de mensen speciale 'begaafdheden' zijn vereist. Het meest duidelijke voorbeeld hiervan is uiteraard de schaker.

14. Doms, Dunne \& Troske (1997) en Autor, Katz \& Krueger (1998) vinden soortgelijke 'upgrading'effecten voor de Verenigde Staten. 


\subsection{Wordt het werk complexer of meer gestandaardiseerd?}

Net zoals een werkgever kan afwegen welk opleidingsniveau hij zal vragen voor een functie, zo kan hij ook de aard van het product variëren door meer nadruk te leggen op de automatiseerbare taak 1 , of juist op de niet-automatiseerbare taak 2 . De keuze van het product dat hij produceert zal afhangen van de kosten en baten die de verschillende combinaties hebben. Als een product verder wordt gestandaardiseerd, zal waarschijnlijk een groter deel van het werk routinematig en automatiseerbaar zijn. De kosten zullen dalen, maar ook de waarde van het product zal dalen. Omgekeerd zal meer maatwerk worden gevraagd voor een grotere inzet van moeilijk automatiseerbaar werk. Dit zal leiden tot hogere kosten, maar het product ook waardevoller maken. Het product dat feitelijk wordt geproduceerd, wordt dus bepaald door een evenwicht van deze factoren. De introductie van ICT-applicaties zal ook dit evenwicht verstoren.

Zoals we hebben aangeven, wordt enerzijds het routinematige deel van het werk (taak 1) door de introductie van ICT goedkoper. Er zal daardoor een neiging bestaan het product meer te standaardiseren. Anderzijds kunnen complementariteiten ook de productiviteit van het niet-geautomatiseerde werk doen toenemen (taak 2). Als dit het geval is, zou er juist weer een neiging bestaan meer maatwerk te gaan leveren. De uiteindelijke veranderingen in het product zullen daardoor dus afhangen van de kostenbesparing op het routinematige deel enerzijds en de opgetreden complementariteitsvoordelen anderzijds.

\section{Conclusies}

De introductie en de diffusie van de computers en ICT heeft de arbeidsmarkt en het economisch landschap drastisch gewijzigd. Veel taken zijn geautomatiseerd en veel werknemers zijn in staat efficiënter te werken. Ook de arbeidsmarkt wordt daardoor in belangrijke mate beïnvloed door computertechnologie in PC's, maar ook in andere ICT -applicaties. Met de verdere diffusie van nieuwe ICT zal het belang van computers en computergerelateerde technologie alleen maar toenemen.

In deze paper zijn we ingegaan op de manier waarop mensen met computertechnologie werken. Op basis van deze analyse van de interactie tussen mens en machine hebben we laten zien welke werkenden ICT-applicaties gebruiken, welke invloed dit gebruik heeft op de inhoud van hun werk en welke implicaties dit heeft voor de vraag naar verschillende soorten arbeid. Bezien vanuit de gangbare visie op de invloed van computers en ICT op de werkgelegenheid zijn onze bevindingen opzienbarend. Net zoals in de jaren zeventig en tachtig ten onrechte een vrees bestond voor grootschalige technologische werkloosheid doordat computers het werk van mensen over zouden gaan nemen, is ook nu de vrees onterecht dat als we niet tijdig investeren in computervaardigheden een deel van de bevolking de boot zal missen. Nieuwe computertechnieken worden weliswaar in eerste instantie meer door hoger opgeleiden dan door lager opgeleiden gebruikt. Ten onrechte wordt hieruit vaak geconcludeerd dat speciale computervaardigheden nodig zijn om deze nieuwe technologie te kunnen 
gebruiken. Het is in eerste instantie niet het hoge opleidingsniveau maar het hoge salaris dat de introductie van ICT bij deze groepen verklaart. Bij werknemers met een hoog salaris levert een beperkte verhoging van de productiviteit immers een grotere kostenbesparing op. Als ICT goedkoper wordt en als er steeds meer interessante applicaties komen zal uiteindelijk - zo verwachten wij - vrijwel iedereen met computertechnologie op de werkplek worden geconfronteerd. Omdat deze nieuwe toepassingen juist bedoeld zijn mensen te ondersteunen in hun werk, zal het gebruik van deze nieuwe techniek weinig problemen opleveren.

Dit betekent echter niet dat niets zal veranderen. Door het gebruik van computertechnologie zal de productiviteit in veel beroepen toenemen. Aan de ene kant zal dit de vraag naar de desbetreffende categorie arbeid verminderen, maar aan de andere kant zal door de lagere productiekosten, ook de productprijs dalen waardoor de vraag weer zal toenemen. Als gevolg van dergelijke processen zullen bepaalde activiteiten in belang toenemen en andere in belang dalen. Omdat we verwachten dat uiteindelijk zowel hoog- als laagopgeleiden ICT-applicaties voor hun werk gebruiken en omdat deze productiviteitsstijgingen de vraag zowel positief als negatief kunnen beïnvloeden, valt hierdoor niet een eenduidige 'skill -biased technical change' te verwachten, zoals we in paragraaf 3 hebben aangegeven.

Doordat ICT-applicaties werkzaamheden van mensen zullen overnemen, zal het belang van de verschillende soorten vaardigheden de komende tijd belangrijke veranderingen ondergaan. Werkgevers zullen op basis van de nieuwe productiemogelijkheden ook nieuwe afwegingen maken over de producten die zij leveren en de wijze waarop binnen een bedrijf wordt gewerkt. Onder bepaalde omstandigheden verwachten we dat meer maatwerk zal worden geleverd, terwijl onder andere omstandigheden standaardisering van de producten zal volgen. Door de verschuiving in het belang van vaardigheden op de arbeidsmarkt zullen sommige mensen profiteren van de veranderingen en andere nadelen ondervinden. Opnieuw verwachten we niet dat dit proces duidelijk in het voordeel van hoger opgeleiden zal werken, omdat niet alleen vaardigheden die met cognitieve intelligentie samenhangen in waarde zullen stijgen.

Een derde consequentie van de verdere doorvoering van ICT is dat mensen zich op hun werk steeds meer kunnen toespitsen op die activiteiten die ook de kern van hun beroep vormen. Veel bijkomstige taken worden immers door de nieuwe technologie overgenomen. Dit betekent dat werkgevers binnen de verschillende beroepen de neiging zullen hebben om de gevraagde kwalificaties te verhogen. De kosten van het hogere loon worden immers gecompenseerd doordat er steeds minder tijd verloren gaat aan taken waarbij deze vaardigheden niet worden gebruikt. Met name vanwege dit argument valt dus toch te verwachten dat de vraag naar hogere opleidingsniveaus zal blijven stijgen. De computerisering van de arbeidsmarkt leidt dus toch tot 'skill-biased technical change'. Deze vorm van 'skill-biased technical change' houdt echter niet in dat er geen werk meer is voor laaggeschoolden en de schaarste aan hoger opgeleiden zal toenemen, waardoor alsnog een tweedeling dreigt te ontstaan. Door het graduele karakter van deze verschuivingen betekent het dat in de tijd die voor ons ligt vrijwel iedereen langer zal studeren en iets meer energie moet steken in het verhogen en onderhouden van zijn kennispeil om daarmee adequaat te kunnen blijven functioneren op de arbeidsmarkt. 
Onze conclusies kunnen dan ook worden samengevat in drie punten.

In de eerste plaats lijkt het ons niet nuttig veel te investeren in computervaardigheden. Het toenemende gebruik van ICT zal vrijwel probleemloos verlopen. Belangrijker is het om goed in de gaten te houden welke verschuivingen plaatsvinden in het belang van allerlei andere vaardigheden. Door hier in het onderwijs tijdig op in te spelen kan een succesvolle integratie van jongeren in de toekomst worden verzekerd.

Als er al beleid nodig is om de integratie van ICT op het werk in goede banen te leiden dan ligt het meer voor de hand om de nadruk te leggen op beleid en regelgeving met betrekking tot de infrastructuur voor ICT (de digitale snelweg), de beschikbaarheid en ontwikkeling van software, enzovoort. Omdat de prijs van ICT-gebruik een belangrijke determinant is in het diffusieproces kan een onderontwikkeld of te duur bedradingsnetwerk of een te afgeschermde softwaremarkt het groeipotentieel ernstig beperken. Omdat de huidige regelgeving op mededingingsgebied voornamelijk gebaseerd is op ervaringen met oude technieken, kan inflexibiliteit op dit gebied veel problemen opleveren.

Hoe de arbeidsmarkt als gevolg van computers en ICT precies zal veranderen is nog niet te zeggen. Dit hangt immers sterk af van de ICT-applicaties die nog moeten worden ontwikkeld, terwijl bovendien de reacties op deze ontwikkelingen zeer complex kunnen zijn. Tenslotte is het daarom van zeer groot belang de ontwikkelingen die de arbeidsmarkt nu ondergaat zeer zorgvuldig in de gaten te houden, omdat alleen dan tijdig duidelijk zal worden in welke richting de arbeidsmarkt zich beweegt. Dit vraagt andere invalshoeken bij onderzoek en dus ook nieuwe (experimentele) dataverzameling, waarin veel meer dan nu het accent moet komen te liggen op de aard en inhoud van het werk, de gevraagde competenties en de beschikbare kennis en vaardigheden van de mensen. Een dergelijk instrument zou zowel onderzoek als beleid moeten dienen. Om ook in de toekomst arbeidsmarktontwikkelingen goed te kunnen volgen zullen de meetinstrumenten op het gebied van het meten van vaardigheden immers verder moeten worden ontwikkeld en zullen onderzoekers de mogelijkheid moeten krijgen om hun inzichten over de ontwikkelingen op de arbeidsmarkt aan de werkelijkheid te toetsen. Voor beleidsmakers kan een dergelijk instrument de basis vormen voor het beleid op het gebied van onderwijs, scholing en arbeid, waarmee ze in staat zijn ook in de kenniseconomie de vinger aan de pols te houden.

\section{Literatuur}

Acemoglu, K.D. (1998), Why do new technologies complement skills? Directed technical change and wage inequality, Quarterly Journal of Economics, Vol. 113, no. 3, pp. 1055-1089.

Anderson, R.E. en A. Ronnkvist (1999), The presence of computers in American schools, (http://www.crito.uci.edu/TLC). 
Ashton, D., B. Davies, A. Felstead, F. Green (1999), Work skills in Britain, ESRC Centre on Skills Knowledge and Organisational Performance (SKOPE), Oxford and Warwick Universities.

Autor, D.H., L.F. Katz, A.B. Krueger (1998), Computing inequality: Have computers changed the labor market? Quarterly Journal of Economics, Vol. 113, no. 3, pp. 1169-1213.

Autor, D.H., F. Levy en R.J. Murnane (2000), Computer cognition and human cognition: The skill content of recent technological change, MIT, werkdocument januari.

Bell, B.D. (1996), Skill-biased technical change and wages: Evidence from a longitudinal data set, Nuffield College, werkdocument juli.

Berman, E., J. Bound, en Z. Griliches (1994), Changes in the demand for skilled labor within U.S. manufacturing industries, Quarterly Journal of Economics, Vol. 109, no. 2, pp. 367-398.

Berman, E., J. Bound, en S.J. Machin (1998), Implications of skill-biased technological change: International evidence, Quarterly Journal of Economics, Vol.113, no. 3, pp. 1245-1279.

Berman, E. en S.J. Machin (2000), Skill-biased technology transfers: Evidence of factor-biased technological change in developing countries, Boston University, werkdocument februari.

Borghans, L., F. Green, en K. Mayhew (2001), Skills measurement and economic analyse, Oxford Economic Papers, Vol. 54, no. 3, te verschijnen.

Borghans, L. en A. de Grip (2000), The overeducated worker? The economics of skill utilization, Cheltenham: Edward Elgar.

Borghans, L. en A. de Grip (2000b), Skills and low pay: Upgrading or overeducation? In: M. Gregory, W. Salverda \& S. Bazen (Red.) Labour market inequalities; Problems and policies of low-wage employment in international perspective, Oxford: Oxford University Press, pp. 198-224.

Borghans, L. en L. Groot (1997), Het belangenconflict tussen sportbonden en kampioenen, Economisch Statistische Berichten, Vol. 82, 4098, pp. 231-232.

Borghans, L. en L. Groot (1998), Superstardom and monopolistic power: Why media stars earn more than their marginal contribution to welfare, Journal of Institutional and Theoretical Economics, Vol. 154, no. 3, pp. 546-571.

Borghans, L. en J. van Loo (1999), Skills measurement and wages, ROA, werkdocument september.

Borghans, L. en B. ter Weel (2000a), Do we need computer skills to use a computer? Evidence from the U.K. ROA and MERIT, werkdocument juni.

Borghans, L. en B. ter Weel (2000), Why pens changed the wage structure and computers did not: The returns to computer and pen use revisited, ROA and MERIT, werkdocument juli.

Borghans, L. en B. ter Weel (2000), What happens when agent T gets a computer? ROA and MERIT, werkdocument augustus.

Bound, J. en G. Johnson (1992), Changes in the structure of wages in the 1980's: An evaluation of al- 
ternative explanations, American Economic Review, Vol. 82, no. 2, pp. 371-392.

Bresnahan, T.F. (1999), Computerisation and wage dispersion: An analytical reinterpretation, Economic Journal, Vol. 109, Features, pp. F390-F415.

Bresnahan, T.F., E. Brynjolfsson en L. Hitt (1998), How do information technology and work-place organization affect labor demand? Firm level evidence, MIT, werkdocument september.

Broer, P. en W. Jansen (1989), Employment, schooling and productivity growt, De Economist, Vol. 137 , no. 2, pp. 425-53.

Card, D., F. Kramarz en T. Lemieux (1999), Changes in the relative structure of wages and employment: A comparison of the United States, Canada, and France, Canadian Journal of Economics, Vol. 32, no. 4, pp. 843-877.

Caroli, E. en J. Van Reenen (1998), Human capital and organisational change: Evidence from British and French establishments in the 1980's and 1990's, University College London, werkdocument maart.

Caselli, F. (1999), Technological revolutions, American Economic Review, Vol. 89, no. 1, pp. 78-102.

Chennells, L. en J. Van Reenen (1998), Establishment level earnings, technology and the growth of inequality: Evidence from Britain, Economics of Innovation and New Technology, Vol. 5, no. 1, pp. 139-164.

Chennells, L. en J. Van Reenen (1999), Has technology hurt less skilled workers? An econometric survey of the effects of technical change and the structure of pay and jobs, Institute for Fiscal Studies Working Paper 99/27, december.

Desjonqueres, T., S.J. Machin en J. Van Reenen (1999), Another nail in the coffin? Or can the trade based explanation of changing skill structures be resurrected? Scandinavian Journal of Economics, Vol. 101, no. 3, pp. 533-554.

DiNardo J. en J.-S. Pischke (1996), The return to computer use revisited: Have pencils changed the wage structure too? NBER Working Paper 5606, juni.

DiNardo J. en J.-S. Pischke (1997), The return to computer use revisited: Have pencils changed the wage structure too? Quarterly Journal of Economics, Vol. 112, no. 1, pp. 291-303.

Doms, M., Dunne, T. en K. Troske (1997), Workers, wages and technology, Quarterly Journal of Economics, Vol. 112, no. 1, pp. 253-290.

Dunne, T., L. Foster, J. Haltiwanger en K. Troske (2000), Wage and productivity dispersion in U.S. manufacturing: The role of computer investment, NBER Working Paper 7465 , januari.

Entorf, H. en F. Kramarz (1997), Does unmeasured ability explain the higher wages of new technology workers? European Economic Review, Vol. 41, no. 6, pp. 1489-1509.

Entorf, H., M. Gollac en F. Kramarz (1999), New technologies, wages and worker selection, Journal of Labor Economics, Vol. 17, no. 3, pp. 464-491. 
Freeman, C. en L. Soete (1994), Work for all or mass unemployment, Londen: Pinter.

Freeman, C. en L. Soete (1997), The economics of industrial innovation, Cambridge MA: MIT Press.

Goldin, C. en L.F. Katz (1998), The origins of technology-skill complementarity, Quarterly Journal of Economics, Vol. 113, no. 2, pp. 693-732.

Green, F. (1999), The value of skills, University of Kent, werkdocument juni.

Green, F., A. Felstead en D. Gallie (1999), Computers are even more important than you thought: An analysis of the changing skill-intensity of jobs, Centre for Economic Performance, werkdocument oktober.

Griliches, Z. (1969), Capital-skill complementarity, Review of Economics and Statistics, Vol. 51, no. 2, pp. 465-468.

Groot, L. en A. de Grip (1991), Technological change and skill formation in the bank sector, Economics of Education Review, Vol. 10, no. 1, pp. 57-71.

Haisken-DeNew, J.P. en C.M. Schmidt (1999), Money for nothing and your chips for free? The anatomy of the pc wage differential, Deutsches Institut für Wirtschaftsforschung, Diskussionspapiere, no. 178, februari.

Hamilton, B.H. (1997), Returns to computer skills and black-white wage differentials, John M. Olin School of Business, werkdocument maart.

Handel, M.J. (1999), Computers and the wage structure, The Jerome Levy Economics Institute Working Paper 285, oktober.

Haskel, J. en Y. Heden (1999), Computers and the demand for skilled labour: Industry- and establishment-level panel evidence for the UK, Economic Journal, Vol. 109, Conference Proceedings, pp. C68-C79.

Hebbink, G. (1991), Employment by level of education and production factor substitutability, The Economist, Vol. 139, no. 2, pp. 379-99.

Katz, L. F. (1999), Technological change, computerization and the wage structure, Harvard University, werkdocument mei.

Katz, L. F. en K.M. Murphy (1992), Changes in relative wages, 1963-87: Supply and demand factors, Quarterly Journal of Economics, Vol. 107, no. 1, pp. 35-78.

Krueger, A. B. (1993), How computers have changed the wage structure: Evidence from microdata, 1984-1989, Quarterly Journal of Economics, Vol. 108, no. 1, pp. 33-60.

Levy, F., A. Beamish, R.J. Murnane en D.H. Autor (1999), Computerization and skills: Examples from a car dealership, MIT, werkdocument november.

Levy, F. en R.J. Murnane (1996), With what skills are computers complements? American Economic Review, Vol. 86, Papers and Proceedings, pp. 258-262. 
Lindbeck, A. en D.J. Snower (2000), Multi-task learning and the reorganization of work: From Tayloristic to Holistic organization, Journal of Labor Economics, Vol. 18, no. 3, pp. 353-376.

Lohberg, R. en T. Lutz (1968), Hoe werkt een computer? Deventer: Kluwer.

Machin, S.J. (1996), Changes in the relative demand for skills, In: A. Booth en D. Snower (Red.) Acquiring skills. New York: Cambridge University Press, pp. 129-146.

Machin, S.J. en J. Van Reenen (1998), Technology and changes in skill structure: Evidence from seven OECD countries, Quarterly Journal of Economics, Vol. 113, no. 3, pp. 1215-1244.

Miller, P.W. en C. Mulvey (1997), Computer skills and wages, Australian Economic Papers, Vol. 36, no. 1 , pp. 106-113.

Murnane, R.J., J.B. Willett en F. Levy (1995), The growing importance of cognitive skills in wage determination, Review of Economics and Statistics, Vol. 77, no. 2, pp. 251-266.

Murphy, K.M. en F. Welch (2000), Wage differentials in the 1990's: Is the glass half-full or half empty? University of Chicago, werkdocument september.

OESO (1994), Employment outlook, Parijs: OESO.

Oosterbeek, H. (1997), Returns from computer use: A simple test on the productivity interpretation, Economics Letters, Vol. 55, pp. 273-277.

Reader, W.J. (1980), Vijftig jaar Unilever, Londen: Heinemann.

Reilly, K. (1995), Human capital and information: The employer size-wage effect, Journal of Human Resources, Vol. 30, no. 1, pp. 1-18.

Ricardo, D. (1821), Principles of political economy and taxation, London.

Sanders, M. en B. ter Weel (2000), Skill-biased technical change: A theoretical framework and a survey of the evidence, MERIT, werkdocument januari.

Soete, L. (1987), Employment, unemployment and technical change: A review of the economic debate. In: C. Freeman en L. Soete (Red.) Technical change and full employment, Oxford and New York: Blackwell, pp. 2-35.

Soete, L. en B. ter Weel (1999), Technologie vraagt om meer persoonlijke vaardigheden, Economisch Statistische Berichten, Dossier Armoede, D15-D19.

Spenner, K.I. (1985), The upgrading and downgrading of occupations, Review of Educational Research, Vol. 55, no. 1, pp. 125-154.

Weel, B. ter (2000), Het einde van de werkloosheid? Nieuwe technologie en oude vaardigheden, in: Rifka Weehuizen (ed.), Toekomst@werk.nl. Reflecties op economie, technologie en arbeid, Stichting Toekomstbeeld der Techniek, pp. 80-89.

Weinberg, B.A. (2000), Computer use and the demand for female workers, Industrial and Labor Review, Vol. 53, no. 1, pp. 290-308. 